ŽELJKO MARUŠIĆ, Ph.D.

Transport Engineering

E-mail: zeljko.marusic@fpz.hr

Review

IZIDOR ALFIREVIĆ, B.Sc.

Accepted: Oct. 24, 2007

E-mail: izidor.alfirevic@fpz.hr

Approved: June 18, 2009

University of Zagreb,

Faculty of Transport and Traffic Sciences

Institute of Aeronautics

Vukelićeva 4, HR-10000 Zagreb, Republic of Croatia

OMER PITA, B.Sc.

E-mail: omer.pita@ccaa.hr

CCAA - Croatian Civil Aviation Agency

Vukovarska 284, HR-10000 Zagreb, Republic of Croatia

\title{
MAINTENANCE RELIABILITY PROGRAM AS ESSENTIAL PREREQUISITE OF FLIGHT SAFETY
}

\begin{abstract}
This article is dealing with airline industry standards regarding reliability reporting and with practical aspects of reliability program deployment within an operator's organization. Reliability program is a tool for monitoring the effectiveness of aircraft maintenance program. Apart from being an effective tool for maintenance program development, the reliability program can bring to light flaws in aircraft design, discrepant operational procedures, discrepancies in line and base maintenance. Reliability program is also considered to provide very valuable means for achieving better operational performance (through decreased maintenance-related problems in operation) and increased flight safety. For this reason, reliability programs are mandated by the regulations for all commercial operators. Even though there is a general industry standard regarding maintenance reliability programs, it still has to be customized and optimized by each operator in order to gain the most out of it. Organizational procedures will vary significantly from one operator to another, reflecting the size and structure of the monitored fleet, size of the operator and its engineering power. As maintenance reliability program involves the application of statistic methods in finding systematic negative trends, the bigger the size of the fleet, the more accurate and reliable results can be achieved. This work is outlining the existing airline industry standards and good practice in carrying out maintenance reliability program.
\end{abstract}

\section{KEY WORDS}

aircraft maintenance program, maintenance reliability program, flight safety, small airline operator

\section{INTRODUCTION}

Modern commercial aircraft maintenance programs are based on MSG-3 (Maintenance Steering Group) analysis. All operators in the initial phase of new aircraft type operation use generic maintenance program largely based on aircraft manufacturer's recommendation. The manufacturer's recommendation is featured in a manual called MPD - Maintenance Planning Document [2]. While developing MPD, the manufacturer is assuming average operational conditions (climate, no geographical specifics, average annual utilization, average flight duration, standard operational procedures). During actual operation of the aircraft, it can be determined that the generic maintenance program as defined in MPD is not adequate in a large number of cases and consequently adjustments of the maintenance program are necessary to suit specific types of operation. Therefore, actual aircraft maintenance program should also reflect the relevant technical and operational environment which is specific to each operator. To facilitate this requirement, the operator's maintenance reliability program should be established. The maintenance reliability program can be defined as a set of organizational procedures and responsibilities dealing with: obtaining and collecting data, statistical analysis of collected data, finding out negative statistical trends and definition of corrective actions to rectify negative trends - improve operation standards from primarily technical aspects, but also trigger changes in operational procedures as well as changes in aircraft system design [3].

The reliability program gives information about the reliability of each specific aircraft system and components as well as about the reliability of the aircraft type [4]. Such information can be further compared with the expected reliability data or, with such data collected for the world fleet of a certain aircraft type. The statistical analysis of the collected relevant data derives statistical trends in reliability which can be positive or negative. Negative trends indicate that 
some system or component is not performing up to the expected standard and that the cause for this behaviour has to be investigated, analyzed, determined and eliminated by proper corrective action.

Reliability is the measure of a system or component stability. The system or component is considered to be reliable if it is functioning within the designed or expected parameters. The system is not reliable when it is functioning outside the designed or expected parameters. It is not possible to make a system or component reliable to the level above its inherent reliability resulting from the design. The decision to make changes to the maintenance program should be based on the reliability program analysis.

The reliability program must be approved by the appropriate Authority either through Maintenance Management Exposition, Maintenance Program or separate manual dealing with Reliability program.

\section{GENERIC FLOW OF RELIABILITY PROGRAM}

Each reliability program should cover the following major steps [8]:

a) collection of relevant maintenance data produced during aircraft operation,

b) statistical analysis of data and identification of negative trends, followed by written reporting,

c) investigation of negative trends, finding root causes,

d) definition of corrective action that will correct negative trends,

e) performance of corrective action.

Constant application of the reliability program in the loop should give feedback information about the effectiveness of corrective actions.

Each step of the reliability program must be defined and specified in writing, thus creating a written program. Such program then defines responsibilities and procedures within the operator's organization which have to be carried out in order to ensure successful functioning of the reliability program.

\subsection{Definition and responsibilities}

It is common practice that overall responsibility for functioning of the reliability program is under the Reliability Control Board which is composed of members from different organizational units from the maintenance department. The Reliability Control Board manages the reliability program in accordance with written procedures. It is authorized for the approval of corrective actions and approval of maintenance program changes that are derived from the reliability program. In order to make decisions, the Reliability Con- trol Board has to hold a meeting which has to be attended by a qualified number (more than half) of the members. The Reliability Control Board is also authorized to:

- approve changes in the reliability program and its very procedures (some of these changes have to be approved by the Authority),

- evaluate and approve the proposed change of the maintenance program as a result of corrective action determined under the reliability program.

\subsection{Role of airworthiness authorities}

The information gathered by the operator through the reliability program is valuable for airworthiness authorities, as it provides concise overview of the performance of an operator [10]. Therefore, it is highly recommended that airworthiness authorities are fully involved in the reliability program process.

Normally, this is achieved through routine distribution of copies of the Reliability Control Board meeting minutes and Monthly reliability reports by the operators to the airworthiness authority.

This provides constant flow of synthetic information about fleet reliability, negative trends, corrective actions and other aspects of the reliability program.

Active participation of airworthiness authority representatives at the Reliability Board meetings gives even more useful information to authorities and can improve also the performance of the operator. The members of the Airworthiness Authorities should have unlimited access to all relevant information related to the ongoing Reliability Program.

\subsection{Collection of data from aircraft operation}

Collection of data on the daily basis, analysis and preparation of reports is normally done by the engineering personnel (reliability engineer). The distribution system of technical records and operational data should foresee that the reliability engineer regularly receives their copy of all the relevant records [5].

The relevant records are:

- data about flight operations (flights, flight hours),

- all maintenance log entries,

- delays and cancellations, specifically technical delays and cancellations,

- other disturbances of operation due to technical reasons,

- unscheduled engine changes,

- technical incidents in the operation (in flight shutdown, smoke in cabin etc.),

- replacements of aircraft components,

- reports about technical problems and defects on the aircraft (Service Difficulty Reports...), 
- records from base maintenance checks including rectification of findings,

- workshop finding reports for components removed from the aircraft.

\subsection{Statistical analysis of collected data}

After all data have been collected in the current month, they have to be statistically analyzed.

First, data are grouped per monitored parameter. For example, all pilots' complaints are gathered, sorted per ATA chapter and summed up. Then, a calculation is done to get the reliability parameter. Example, divided by the number of flights in the monitored period, multiplied by 100 to get the number of events per 100 flights. After the calculation of all the monitored parameters has been done, such data are entered in a reliability table and a reliability diagram is charted [9] .

\section{PARAMETERS DEFINED IN THE RELIABILITY PROGRAM}

The operator can vary the number of parameters which are analyzed in the reliability program, the basic standard parameters being:

- number of pilot complaints per 100 flights,

- number of technical delays above 15 min and cancellations per 1000 flights,

- number of component replacements per 1000 component flight hours,

- number of unscheduled component replacements per 1000 component flight hours,

- number of engine in-flight shutdowns per 1000 engine hours,

- number of unscheduled engine changes per 1000 engine hours,

- repetitive pilots complaints,

- long lasting technical problems with defect rectification (service difficulty reports),

- significant findings during scheduled base maintenance events.

\subsection{Upper control limits (alert values)}

The essence of the reliability program is the statistical control over process. To establish such control, the statistical alert values (UCL) have to be defined for each monitored parameter. The alert value is used to determine the acceptable deviation from the mean value and to recognize and react to the significant deviations from statistically acceptable limits in reliability [1].

The repeated increase of the alert value represents a negative trend which has to be stopped by the application of appropriate corrective action. The repeated increase in three consecutive months is considered to be confirmed a negative trend and corrective action taken by the Reliability Control Board is mandated. Upper control limit is based on the statistical calculation of the standard deviation covering the recent twelve-month period.

\subsection{Procedure of establishing UCL:}

a) Calculation of the standard deviation:

$\sigma=\sqrt{\frac{\sum\left(x^{2}\right)-\frac{\left(\sum x\right)^{2}}{N}}{N-1}}$

where:

$$
\begin{aligned}
x= & \text { monthly value of parameter in observed } \\
& \text { months, } \\
\sigma= & \text { standard deviation, } \\
N= & \text { number of observed months for which stan- } \\
& \text { dard deviation is calculated. }
\end{aligned}
$$

b) Calculation of Upper Control Limit - UCL:

$\mathrm{UCL}=\bar{x}+k \sigma$

where:

$\bar{x}=\sum x / N$

$k=$ deviation factor (normally between 2 and 3 )

This calculation of upper control limit (UCL) should be repeated every 12 months. The upper control limit can be increased or decreased maximally by $10 \%$ compared to the previous UCL. Exceptionally, the Reliability Control Board can approve larger changes of UCL.

\subsection{Limit for new aircraft type}

Upper control limits are established based on historical data (one year of operation). For new aircraft type in the fleet, such historical data are not available. In such situations there is a guideline for determining UCL within 15 months of operation.

- in the first six months of operation the reliability is monitored without the established UCL,

- at the end of the six-month period, a temporary UCL is established. This temporary UCL is used for next 9 months of operation,

- after 9 months (total 15 months since introduction of the aircraft type) new final UCL is calculated based on the last 12 months of operation.

\subsection{Artificial UCL}

Artificial UCL is used for certain aircraft components in the situation when there is no history on component removals available. This artificial UCL is maintained until enough historical data are accumulated to be able to establish normal UCL by calculation of standard deviation. 


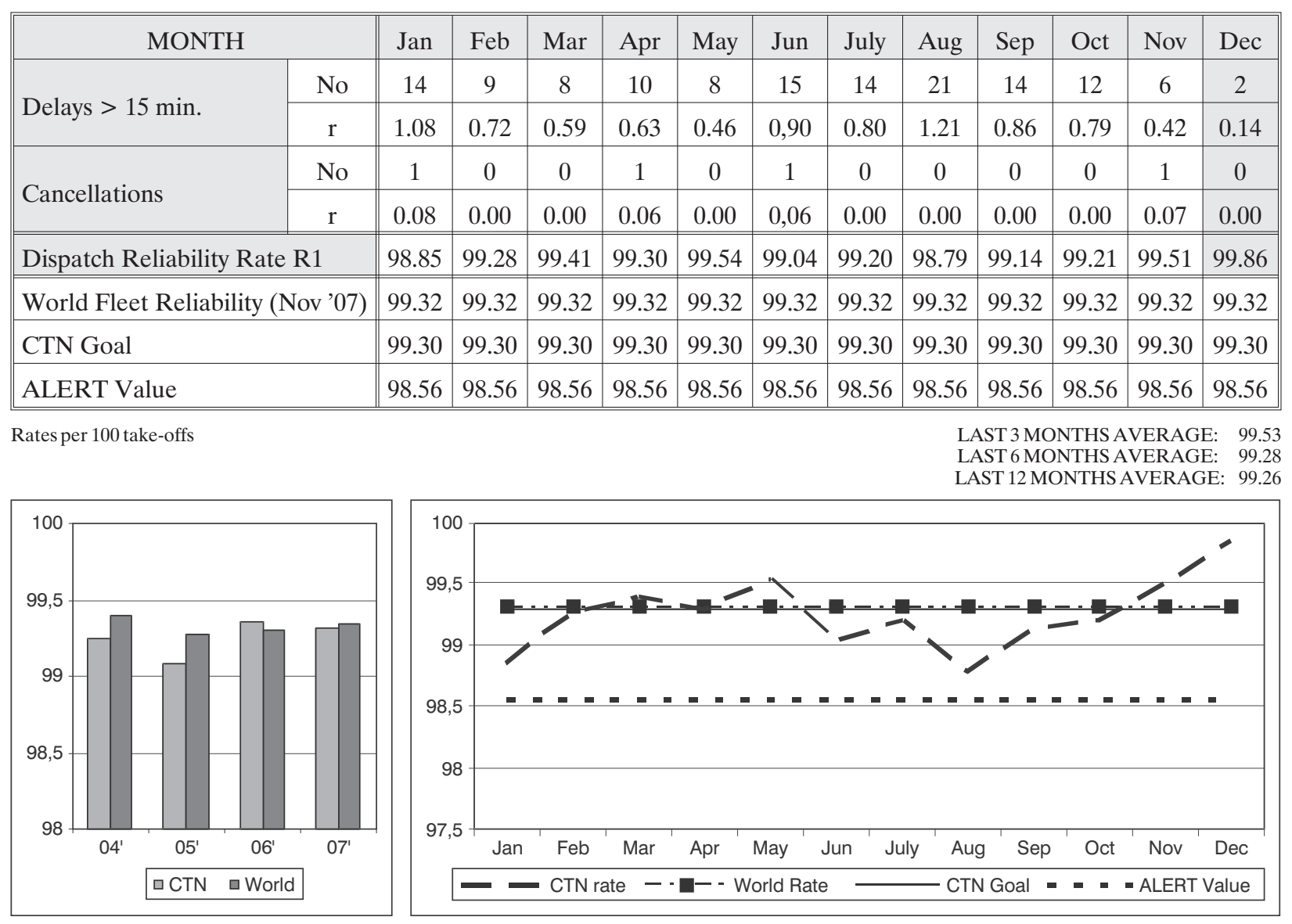

Figure 1 - Sample page from Monthly reliability report - Technical Dispatch Reliability Rate source: Croatia Airlines, Monthly Reliability Report, December 2008

\section{PRESENTATION AND ANALYSIS OF STATISTICAL DATA}

For the purpose of analysis it is necessary to present statistical information. A common way of the presentation is Monthly reliability report (Monthly Fleet Reliability Report) in which all the reliability data will be displayed in a concise form (see Tables and Diagrams, Figures 1 and 2) sorted by category.

From these reports it is easy to recognize the trends of parameters.

Monthly reports are published for each aircraft type separately. It serves as the basis for further analysis of negative trends and subsequent definition of corrective action.

Normally, it is published by the reliability engineer or the engineering department.

\subsection{Analysis of data}

When some of the parameters exceed the upper control limit for three subsequent months, it is necessary to analyze and find out the cause for such a trend. This analysis is normally done by the engineering department. The results of the analysis which should point to the source of negative trend are presented at the RCB meeting together with the Monthly report. The analysis procedure includes detailed investigation of all the relevant events that have contributed to the negative trend and finding the cause of these events [7]. Typical causes of negative trends are:

- inadequate preventive maintenance, inefficient maintenance program,

- lack of knowledge of the maintenance personnel,

- insufficiently specified maintenance procedures,

- defined maintenance procedures are not strictly followed by the maintenance personnel,

- unserviceable tooling and equipment for maintenance,

- unserviceable GSE (Ground Support Equipment),

- sudden changes in operation type,

- disrespect of defined pilot procedures,

- operation of aircraft close to certification limits.

\subsection{Corrective action}

During the analysis of the negative trend, the engineering department finds out the cause of such deviation and recommends necessary corrective actions that will effectively return the observed parameter 


\begin{tabular}{|l|c|c|c|c|c|c|c|c|c|c|c|c||}
\hline \multicolumn{1}{|c|}{ MONTH } & Jan & Feb & Mar & Apr & May & Jun & July & Aug & Sep & Oct & Nov & Dec \\
\hline \hline Comp. unscheduled removals & 35 & 13 & 26 & 14 & 20 & 33 & 38 & 32 & 40 & 47 & 30 & 39 \\
\hline No. of components & 1760 & 1760 & 1760 & 1760 & 1760 & 1760 & 1760 & 1760 & 1760 & 1760 & 1760 & 1760 \\
\hline Comp. Reliability Rate R2 & 0.014 & 0.006 & 0.010 & 0.004 & 0.005 & 0.009 & 0.010 & 0.008 & 0.011 & 0.014 & 0.012 & 0.015 \\
\hline
\end{tabular}

Rate per 1000 components hours LAST 3 MONTHS AVERAGE: 0.014

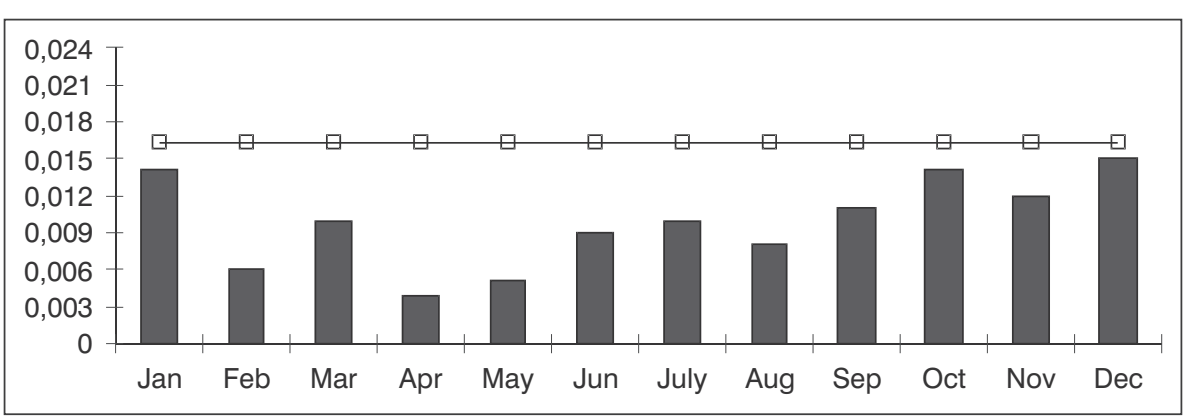

Figure 2 - Sample page from Monthly reliability report - Component Reliability Rate

source: Croatia Airlines, Monthly Reliability Report, December 2008

back to the normal stabile level. Examples of corrective actions are:

- change of task interval in maintenance program or change in the work content,

- revision of certain scheduled maintenance tasks,

- additional inspections fleet wide with incentive to determine the condition of critical systems or components,

- fleet wide modification of aircraft,

- change in maintenance procedures,

- training of maintenance personnel, flight crews or other operational staff.

The Reliability control board monitors the performance of corrective actions. At each meeting all the current corrective actions are reviewed and the status of each corrective action determined. If required, the corrective actions that have been delayed without any proper reason are enforced.

\section{CASE STUDY: ANALYSIS OF INCREASED UTILISATION INTENSITY IMPACT ON TECHNICAL DISPATCH RELIABILITY}

The fleet reliability data of the Croatia Airlines during the period between 2002 and 2008 were analyzed. The technical dispatch reliability was the chosen parameter since it represents a synthetic parameter indicating the general technical status of the aircraft type fleet, rather than a series of specific parameters like components and systems reliability, pilots discrepancies etc.

To test the thesis that an increase in utilisation above the optimal level results in decreased reliability, two distinctive seasons (summer and winter flight schedules) were chosen. The winter season included the period from October to March inclusive, while the summer season analysed the period from April to September. The results are presented in Tables 1 and 2.

Analysis of data from the above presented tables indicates the following:

- Like many other air carriers Croatia Airlines has distinctive seasonal utilisation difference. During summer period the fleet utilisation is about $34 \%$ higher than during the winter period.

- Considering the route structure of Croatia Airlines it is evident that an average of 9 flight hours daily utilization per aircraft represents maximum utilization.

- It confirms the thesis that the increase of aircraft utilisation during the summer period results in decreased technical dispatch reliability. During all the considered periods from 2002 to 2008 the reliability decrease in summer compared to winter seasons (see Figure 3) is evident. In 2005, during the summer period the utilisation reached its maximum of 9.1 daily flight hours per aircraft, causing technical dispatch reliability of $98.85 \%$, which is the lowest value in all the considered periods.

\subsection{Reasons for technical dispatch reliability decrease}

Analysing the specific parameters, one can extract the following main effects that generated technical dispatch reliability decrease during the summer season:

1. Insufficient fleet redundancy - capacity during the summer season; during the summer period a $100 \%$ of fleet is utilized and in case of any aircraft dropout due to malfunction, it is impossible to re- 
Table 1 - Average daily utilisation in flight hours per aircraft $\mathrm{A320}$ fleet of Croatia Airlines in winter and summer season during period 2002 - 2008 (source: Monthly Fleet Reliability Report - CTN)

\begin{tabular}{||c|c|c||}
\hline Year & $\begin{array}{c}\text { Winter schedule } \\
\text { (daily flt hrs/ air- } \\
\text { craft) }\end{array}$ & $\begin{array}{c}\text { Summer schedule } \\
\text { (daily flt hrs/ air- } \\
\text { craft) }\end{array}$ \\
\hline 2002 & 5.42 & 8.06 \\
\hline 2003 & 6.02 & 8.03 \\
\hline 2004 & 5.74 & 8.37 \\
\hline 2005 & 5.6 & 9.1 \\
\hline 2006 & 5.9 & 8.63 \\
\hline 2007 & 6.03 & 8.52 \\
\hline 2008 & 6.89 & 8.53 \\
\hline
\end{tabular}

place it, as there are no redundant capacities available. During the winter season there is about $34 \%$ difference in capacity, where $17 \%$ of aircraft are excluded from the operation for heavy maintenance and $17 \%$ of fleet is available as redundant capacity in case that some aircraft drops out.

2. Climatic effects; during the summer season, due to higher temperatures, increased wear of tires and brakes is evident. The replacement of
Table 2 - Average technical dispatch reliability of aircraft $\mathbf{A} 320$ fleet of Croatia Airlines in winter and summer season during period 2002 - 2008 (source: Monthly Fleet Reliability Report - CTN)

\begin{tabular}{|c|c|c||}
\hline Year & $\begin{array}{c}\text { Winter sch. } \\
\text { (technical dispatch } \\
\text { reliability) }\end{array}$ & $\begin{array}{c}\text { Summer sch. } \\
\text { (technical dispatch } \\
\text { reliability) }\end{array}$ \\
\hline 2002 & $99.27 \%$ & $99.04 \%$ \\
\hline 2003 & $99.20 \%$ & $99.05 \%$ \\
\hline 2004 & $99.51 \%$ & $98.97 \%$ \\
\hline 2005 & $99.28 \%$ & $98.85 \%$ \\
\hline 2006 & $99.39 \%$ & $99.24 \%$ \\
\hline 2007 & $99.61 \%$ & $99.05 \%$ \\
\hline 2008 & $99.38 \%$ & $99.18 \%$ \\
\hline
\end{tabular}

worn-out tires and brakes is the most common cause of delays during the summer period. Additionally, structure damaged due to lightning strikes is also more present during the summer periods.

3. Limited available time for aircraft maintenance; often, cause of delays is late finish of maintenance tasks (mostly over-night) due to the complexity of specific work and high ground time for performance of some maintenance tasks.

\begin{tabular}{|c|c|c|c|c|c|c|c|c|c|c|c|c|c|}
\hline \multicolumn{2}{|c|}{ MONTH } & Jan & Feb & Mar & Apr & May & Jun & July & Aug & Sep & Oct & Nov & Dec \\
\hline \multirow{3}{*}{$\begin{array}{l}\text { Tyre } \\
\text { Removals } \\
\text { Rate * }\end{array}$} & No & 17 & 17 & 23 & 22 & 36 & 33 & 46 & 35 & 29 & 26 & 21 & 21 \\
\hline & Total No & 6 & 6 & 6 & 6 & 6 & 6 & 6 & 6 & 6 & 6 & 6 & 6 \\
\hline & R9 & 0.218 & 0.228 & 0.282 & 0.233 & 0.346 & 0.328 & 0.440 & 0.337 & 0.296 & 0.284 & 0.246 & 0.252 \\
\hline \multicolumn{2}{|c|}{ CTN Tyre MTBR** } & 460 & 436 & 355 & 430 & 289 & 305 & 227 & 297 & 338 & 353 & 406 & 397 \\
\hline \multicolumn{2}{|c|}{ World fleet Tyre LPO*** } & 310 & 310 & 310 & 310 & 310 & 310 & 310 & 310 & 310 & 310 & 310 & 310 \\
\hline
\end{tabular}

* Rate per 100 landings

** Mean Time Between Removal (MTBR)

LATEST 3 MONTHS RATE AVERAGE: 0.261 LATEST 12 MONTHS “MTBR" AVERAGE: 358
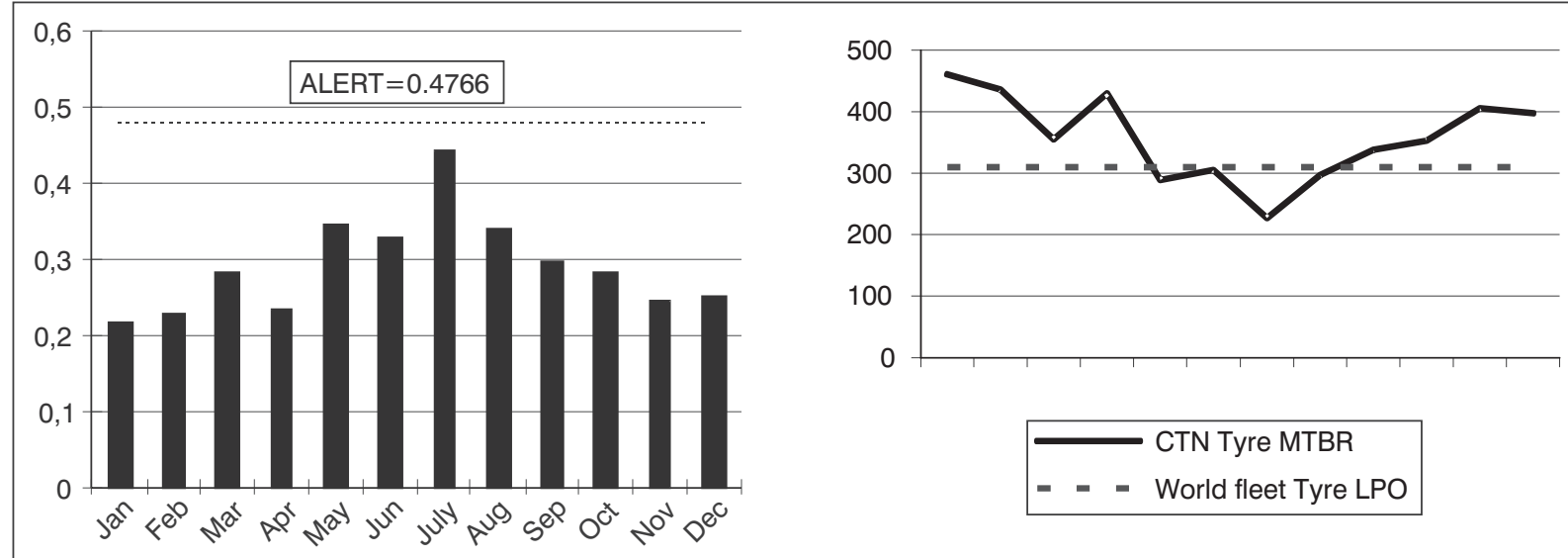

Figure 3 - Tyre Removals Rate indicating higher removal rate in summer months

Source: Croatia Airlines, Monthly Reliability Report, December 2008 


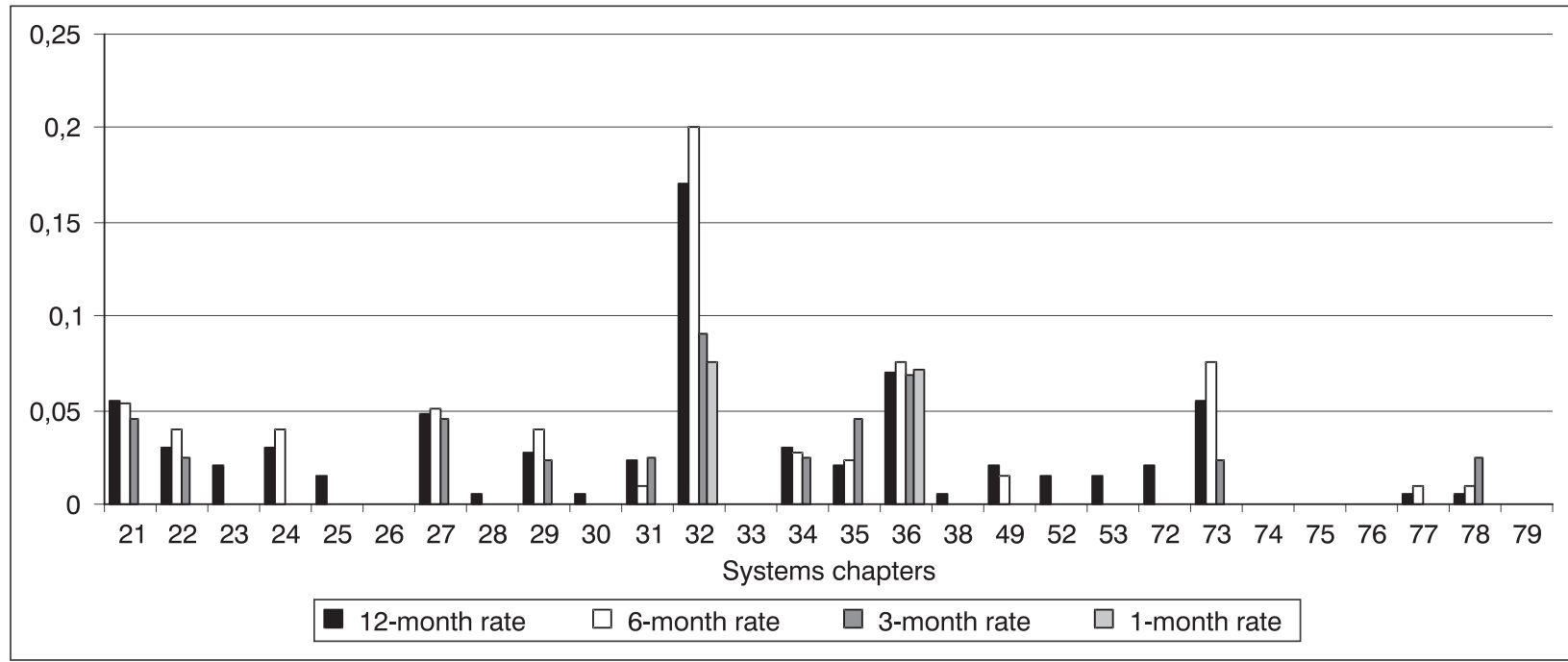

World Fleet Top 6 Range (A319):
1. ATA 32
2. ATA 27
3. ATA 34
4. ATA 21
5. ATA 36
6. ATA 23

World Fleet Top 6 Range (A320):

1. ATA 32

2. ATA 27

3. ATA 21

4. ATA 29

5. ATA 36

6. ATA 34
CTN Top 6 Items (24-months period)

$\begin{array}{ll}\text { 1. ATA 32 } & \text { 25 MLG/NLG Tire worn out } \\ & 9 \text { Oil leakage on NLG or MLG } \\ & 5 \text { Cut found at tire } \\ & 4 \text { LGCIU fault } \\ & 6 \text { Brake block overheat } \\ & 2 \text { Drifting of aircraft } \\ & 2 \text { Brake block worn out } \\ & \text { 1 Indication not downlocked } \\ & \text { Various reasons } \\ & \text { 12 "ELAC 1/2 (PITCH) FAULT" } \\ & 4 \text { Flight Control Slat system fault } \\ \text { 2. ATA 27 } & \text { Various reasons } \\ & \text { 12 ENG \#1 or \#2 Bleed fault } \\ & 9 \text { Problem with PRV } \\ \text { 3. ATA 36 } & \text { Various reasons } \\ & 9 \text { ADIRU fault (IR or ADR) } \\ & \text { Various reasons } \\ \text { 4. ATA 34 } & \text { 2 ENG drain mast fuel leak } \\ & \text { Various reasons } \\ \text { 5. ATA 73 } & \text { 6 Pack 1 or 2 Fault } \\ & \text { Various reasons } \\ \text { 6. ATA 21 } & \end{array}$

Figure 4 - Technical Dispatch Reliability - delays per ATA chapter indicating ATA 32 (wheels and brakes) as major cause of delays

Source: Croatia Airlines, Monthly Reliability Report, December 2008

4. Combination of more incompatible discrepancies on the aircraft; delayed maintenance tasks due to the reduction and lack of available maintenance time (caused by increased utilisation demands) may lead to discrepancies saturation, which combined may represent the safety risk, so that the incompatible discrepancies must be resolved before further flights.

5. Human factors; during intensified utilisation, the airport service personnel, flight crews as well as technical personnel are exposed to higher pressure and workload, which causes greater number of mistakes and may result in the degraded technical status of the aircraft.

\subsection{Corrective actions and measures for maintaining acceptable level of technical dispatch reliability under increased utilization demands}

Basically, the recommended measures to maintain the acceptable level of technical dispatch reliability are:

- Extremely precise maintenance planning in order to maximize the efficiency to perform $\mathrm{vv}$ tasks within reduced maintenance available time.

- High degree of coordination between air carrier's operating departments (flight operations, maintenance, ground operations), as well as coordination 


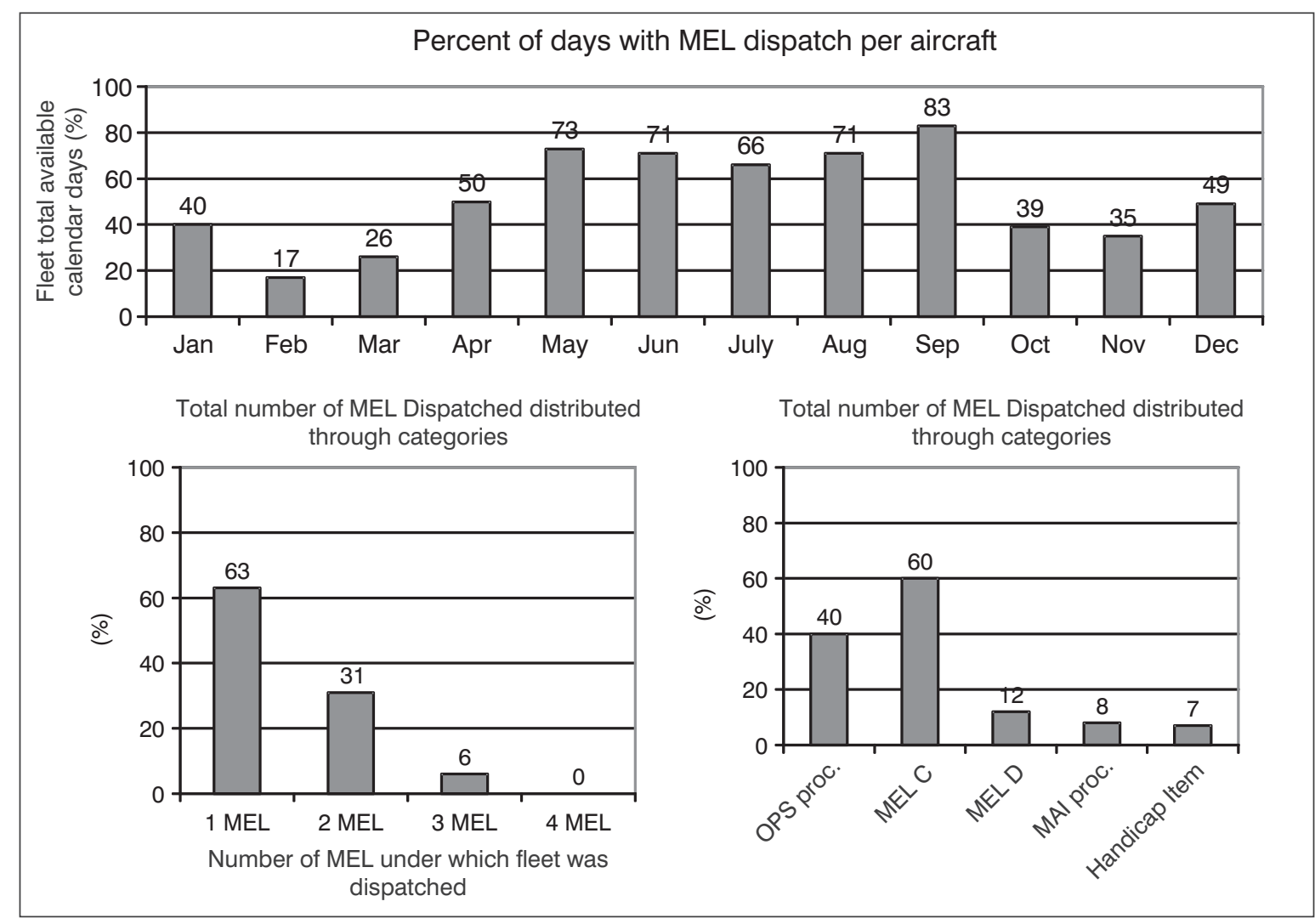

Figure 5 - MEL Dispatch - number of departures with MEL items indicating increased number of MEL dispatches in summer season

Source: Croatia Airlines, Monthly Reliability Report, December 2008

between air carrier and airports, by which optimal reaction can be achieved in case of technical problems.

- Incorporating additional schedule for the maintenance shifts and increasing the resources for night shift. This can lead to maximized efficiency within the reduced available time for over-night maintenance.

- Incorporating on call stand-by duty maintenance personnel in shift plan to resolve sudden unplanned maintenance surges. Shifts schedule has to be in accordance with human factors principles to avoid work overload.

- Focus should be set on preventive actions that produce best results with minimum work hours involved (for example, to plan preventive exchange of tires, before accepted wear tolerance is reached).

- Increasing of motivation of all human resources to achieve maximum efficiency and utilisation within regulatory standards.

\section{CONCLUSION}

The reliability program is mandated by all the current aviation regulators for all commercial aircraft operators in transport aircraft category. First, the reli- ability programs have been developed and recommended in the 1960s and early 1970s by FAA. Basically, the reliability program represents the application of achievements from other industries that have developed statistical methods for the quality control of the manufacturing processes (e.g. mass production of electronic components) in the period after the Second World War.

A properly maintained reliability program enables the operators to monitor and gradually improve the fleet reliability by optimizing the maintenance program and taking other measures in improving its organization. The reliability program discovers the problems in the operators system and trends that are triggered by many events. Such problems have large impact on the flight safety and/or economics of an operator.

The efforts involved in proper data collection, statistical analysis, definition and accomplishment of corrective actions has large return in the increased quality of aircraft maintenance, technical status of the aircraft and increased flight safety. The case study has shown that the change of one prime parameter of operation (utilization) induces change in reliability. By analysing such a reliability change, corrective measures can be defined in order to keep the reliability parameters within acceptable limits. 
Dr. sc. ŽELJKO MARUŠIĆ, dipl. ing.

E-mail: zeljko.marusic@fpz.hr

IZIDOR ALFIREVIĆ, dipl. ing.

E-mail: izidor.alfirevic@fpz.hr

Sveučilište u Zagrebu, Fakultet prometnih znanosti

Zavod za aeronautiku

Vukelićeva 4, 10000 Zagreb, Republika Hrvatska

OMER PITA, dipl. ing.

E-mail: omer.pita@ccaa.hr

CCAA - Croatian Civil Aviation Agency

Vukovarska 284, 10000 Zagreb, Republika Hrvatska

\section{SAŽETAK}

\section{PROGRAM POUZDANOSTI ODRŽAVANJA KAO OSNOVNI PREDUVJET ZA SIGURAN LET}

Ovaj članak obrađuje standarde zrakoplovne industrije, vezane uz izvješćivanje pouzdanosti i praktične aspekte uspostave programa pouzdanosti u zrakoplovnoj organizaciji. Program pouzdanosti je alat za nadzor učinkovitosti programa za održavanje zrakoplova. Osim što je to djelotvoran alat za razvoj programa održavanja, program pouzdanosti može rasvijetliti nedostatke u konstruiranju zrakoplova, nepravilnosti operativnih procedura te nepravilnosti u linijskom i temeljnom održavanju. Program pouzdanosti pruža vrijedne podatke za postizanje boljih operativnih performansi (kroz smanjenje problema vezanih uz održavanje zrakoplova u eksploataciji) $i$ povećanje sigurnosti letenja. Stoga je program pouzdanosti obvezujući kroz zrakoplovnu regulative, za sve komercijalne operatere. Ovisno o veličini operatera, primjena programa pouzdanosti može biti provedena različitim organizacijskim oblicima. Cilj ovog rada je ukratko prikazati uobičajena zajednička praktična rješenja za uspostavljanje programa pouzdanosti. Kroz studiju slučaja na primjeru tvrtke Croatia Airlines pokazano je da promjena karaktera operacije (ljetni prema zimskom red letenja) generira mjerljive promjene u pouzdanosti koje su vidljive u programu praćenja pouzdanosti, te da je za različite vrste operacije potrebno prilagoditi raznim mjerama sustav održavanja svakom tipu operacije.

\section{LITERATURE}

[1] Marušić, Ž., Galović, B., Pita, O., Optimizing Maintenance Reliability Program for Small Fleets, Transport, Vol. XXII, No 3, 174-177, Vilnius, 2007

[2] Kinningson, H., Aviation Maintenance Management, McGraw Hill, New York, 2004

[3] Dhillon, B. S., Maintainability, Maintenance, and Reliability for Engineers, Taylor \& Francis Group, Boca Raton, 2006

[4] Document AC-120-17A, Federal Aviation Administration, Washington, 1978

[5] Maintenance Engineering Evaluation - Appendix F, Boeing, Seattle, 1995

[6] Part M (EC2042), EASA, Brussels, 2003

[7] Zere, I., Appendices To Boeing Maintenance Engineering Evaluations. Seattle, Appendix F - Maintenance Reliability Program, 1995

[8] O'Connor, P. D. T.: Practical Reliability Engineering, John Wiley\&Sons, Ltd, West Sussex, England, 2002

[9] Enga, J.: Aircraft inspection \& maintenance records, Jeppensen \& Co. GmbH, Germany, 2000

[10] Joint Aviation Regulations JAR OPS-1, Joint Aviation Authority, 2007

[11] Webster, J. M., Method and Apparatus for Non-Destructive Inspection of Composite Materials and Semi-Monocoque Structures, US Patent No. 505,090, 1996

[12] Albert, R., Pamber, W., Garrison, J. and Reyna, D., Aircraft Inspection with a Portable, Filmless X-ray System using Reverse Geometry, Materials evaluation, May 2000, pp. 643-645

[13] Green, R. E., Emerging Technologies for NDE and Aging Aircraft Structures, Proceedings of the Workshop on Intelligent NDE Sciences for Aging and Futuristic Aircraft, C. Ferregut, R. Osegueda, and A. Nunez, (Eds.), Univ. of Texas at El Paso, 1997, pp. 267-278

[14] Baker, A. A., Rose, L. R. F. and Jones R., (Eds.), Advances in the Bonded Composite Repair of Metallic Airframe Structures, Elsevier, 2002 